\title{
Multilingualism in Botswana: The Case of Muzi* Primary School
}

\author{
Lydia Nyati-Saleshando \\ Department of Primary Education, Faculty of Education, University of Botswana, Gaborone, Botswana \\ Rosinah T. Mokotedi \\ Department of Primary Education, Faculty of Education, University of Botswana, Gaborone, Botswana
}

\begin{abstract}
This paper presents findings on a case study of how the language in education policy was being implemented at Muzi Primary School. To provide the context, a description of the development of the language in education policy from independence to present period is provided. The study aimed to address the following questions: 1 . What factors did teachers perceive to contribute to the low performance of the school? 2. What role did language of instruction play in the learning process? 3. What attitudes were portrayed or displayed by teachers and how did these affect learning? 4 . What were the implications of findings to nationbuilding, democracy, and social integration? The paper argues that the language policy, which promoted monolingualism, was a failure to acknowledge reality and an impediment to learning, a negation of democratic principles and a hinderance to social integration. The school context demonstrated how the education policy fostered monolingualism in a multilingual context and this negatively impacted on learning.
\end{abstract}

Index Terms - Botswana, multilingualism, Wayeyi, multilingualism, democracy

\section{INTRODUCTION}

The village of Muzi is situated in the Okavango sub-district in the main Northwest district of Botswana. The dominant ethnic groups are the Hambukushu and Wayeyi who are bilingual in mother tongue and Setswana, the national language. The Hambukushu use their language in daily activities, hence the language is passed onto the children. Wayeyi children do not speak Shiyeyi but comprehend when spoken to. In the school the Wayeyi children had a cultural dance group.

The academic performance of Muzi Primary School had been of concern for several years since its inception, like most schools in the sub-district. For instance, in 2000, the school had the lowest pass rate of $44 \%$ in the Northwest District (BEC, 2000-2020). The performance in Setswana language as a subject had the lowest pass rate of $51 \%$ in the district. In 2019 the school performance was at 48\% (BEC, 2000-2020). In 2020, the school was one of the worst in the sub-district at the pass rate of 43\% (BEC, 2000-2020). In 2021, there were 36 teachers from eleven (11) ethnic groups, 19 were speakers of Setswana as a first language (from five (5) Tswana ethnic groups), four (4) Wayeyi, four (4) Kalanga, one (1) Hambukushu, four (4) Herero, two (2) Babirwa and two (2) were Batswapong. There was no ethnic data on students, but teachers estimated that there were more Hambukushu, followed by Wayeyi and a few other groups.

\section{The Development of the Language Policy in BotswanA}

Botswana's language policy was not written but inferred and understood until 1994 (Republic of Botswana, 1994). From independence to the current period Setswana language and culture is regarded as the national language of the country (Republic of Botswana, 1985, p.8; Mokibelo, 2014). It is the language of national pride and unity, the language of cultural identity (National Commission on Education (NCE), 1977). English is the official language, the language of the Government, business, trade, and international cooperation (Mokibelo, 2014; Nyati-Saleshando, 2011). In recent years, it has become the main language of communication in the homes of the elite, and among teenagers and young adults in their social interactions (Mibenge, 2016). The policy did not recognize the rest of the 28 languages spoken in the country.

At independence, there was no clear policy on language of instruction, but practice indicated that Setswana was used as medium of instruction for at least two years. In standard three, English became the medium of instruction up to tertiary level and Setswana was a subject. The First National Commission on Education (1977) viewed this situation as one that neglected the mother tongue, resulting in many children performing poorly in Setswana subject and hence its exclusion from overall grade mark. The Commission further observed that most children fail to attain literacy in the national language. They advocated for national and cultural identity using the national language Setswana and stated

* Muzi is a pseudo name 
that there is 'educational advantage in learning literacy and other skills through the national language first, before moving on to another' (p. 76). This argument was not seen as relevant for other linguistic groups who did not speak Setswana as mother tongue. The commission then recommended that Setswana be the medium of instruction from standard one to four, and English thereafter.

The second National Commission on Education reversed this decision and recommended that English be medium of instruction from standard two by the year 2000 which was revised by the National Assembly to read 'as soon as it is practicable' (Republic of Botswana, 1994, p.59). The decision to reverse the previous Commission's recommendation caused great controversy amongst the Commissioners, causing two camps within this Commission.

Camp A embraced the recommendation of the first Commission (Setswana from standard one to four) while Camp B embraced old practice as at independence (Setswana for only one year, then English). A compromise was reached by allowing the minority view of those in Camp A to be contained in the famous eight-page appendix $F$ in which arguments for mother tongue literacy were clearly articulated and recommendations for developing mother tongue literacy including minority languages were stated.

Those who argued for mother tongue literacy (Camp A of Second Commission) advanced similar arguments as the First National Commission on Education as stated above. Those who argued for early English medium of instruction (Camp B of the Second Commission) stated the good old-fashioned arguments such as the problems of dealing with many languages, teacher training and the burden of translating instructional materials. The Commission stated that 'the present language policy denies the child mastering of the main language (English) needed for better achievement in primary schools and in further education and in working life' (National Commission on Education, (NCE,1993, p.113).

Regarding minority languages, the first Commission did not make any recommendation on their use in education. The second Commission recommended that 'where parents request that other local languages be taught to their children, the school should make arrangements to teach them as a co-curricular activity' (NCE,1993, p.115). However, this recommendation was rejected by Parliament on grounds that this may put pressure on government to support even when resources were scarce. The Minister of Basic Education has indicated that eleven (11) local languages will be introduced in schools in 2022 (Xinhua, 2021). Planning for material development and consultations with communities is currently on-going.

When taking a critical look at the above arguments by the commissions, one notes that they were influenced by certain theoretical orientations, since how language planners view language sets the direction of how they go about solving language problems (Alstad \& Sopanen, 2020). In other words, the arguments were influenced by certain beliefs on what language is and how it is best learned and its role in society (Nyati-Ramahobo, 1999).

\section{TheORETICAL PERSPECTIVES}

Ruiz (1984, p. 16) defines orientations as 'a complex of dispositions toward language and its role... [which] are related to language attitudes in that they constitute the framework in which attitudes are formed'. He proposed three orientations toward language planning: language as a problem, such as the problem of which language to choose for use for official purposes in a multilingual society; language as a right, such as the right to operate in one's language of choice; and language as a resource, to be developed, nurtured, valued, and planned. Underlying these orientations are socio-cultural and socio-political goals for the languages (Hult and Hornberger, 2016). For instance, if the socio-cultural goal is to assimilate all minority groups, then language is likely to be viewed as a problem in which all minority languages must be eradicated. On the other hand, if the societal goal is to achieve linguistic and cultural pluralism, then it is likely that the languages will be viewed as a right and a resource to be harnessed. In this case most languages would be recognized in one way or the other and their cultures preserved.

In addition to orientations in language planning, there have been various bilingual education models which have been studied as they operate around the world. Bilingual education is defined by most scholars using more than one language for instruction in subject areas including language itself (Brutuo, 2021; Benson, 2020; Duplessis and Tebategeza, 2010; Fishman, 1976; Hornberger, 1987 and 1990). In some cases, one of the two languages is the child's first language. Generally, there is agreement in the literature that there are at least four basic models of bilingual education currently in operation:

\section{A. The Transitional Model}

In this model the child uses the first language (L1) as medium of instruction at the initial stages and later switches to the second language (L2) as medium of instruction (L1->L2) (Nyati-Ramahobo, 1999). The first language is used only as an interim means to master the second language and as soon as students are considered proficient enough to comprehend and work academically in the second language, then the second language becomes the medium of instruction in all subjects. Transitional programs are sometimes referred to as remedial or subtractive, for their purpose is to remedy language deficiencies of children who are not competent in English and as soon as this is achieve, the language is subtracted (Bretuo, 2021; Conklin and Lourie, 1983; Trueba, 1979). It is recently viewed as a supporting program by using the first language at initial stages while the goal is to educate the child in English (Massachusetts Department of Elementary and Secondary Education (MDESE), 2020). However, the first language is viewed as less important hence a transition is made to English. In most instances, this model results in cultural assimilation and native 
language loss (Nyati-Saleshando, 2018b; Alidou, 2010). This is the commonest model in Africa in which a local language is used as medium of instruction for three to four years of primary schooling after which a transition is made to English or any other European language.

\section{B. Maintenance Model}

In a maintenance model, the child's first language is used for instruction at the initial stages and later the second language is added on as a medium of instruction $(\mathrm{L} 1+\mathrm{L} 2)$. Sometimes referred to as the additive model, since the second language is added on to the first one. Students in this program 'receive content-area instruction in both languages equally throughout their school career' (Ovando and Collier, 1985, p.39). The aim of a maintenance program is "ensure the continuation and development of the child's linguistic skills in the first language, for both social and academic interaction, and the acquisition of the second language" (Trueba, 1979, p.56). The advantages of a maintenance program are that students gain English proficiency without neglecting their mother tongue or home language (Silaban, 2020; Ovando and Collier, 1985), and as such it affirms cultural rights and ethnic respect (Hornberger, 1990; Hamman-Ortiz and Palmer, 2020).

\section{An Enrichment Model}

It 'encompasses all those bilingual education program types which aim toward not only maintenance but development and extension of the minority languages' (Hornberger, 1990, p.8). These program types include both one way and two-way immersion programs. In a one-way program, one group learns in the other group's L1 and in a two way both groups learn in each other's L1(Ovando and Collier,1985; Nyati-Saleshando, 2018b; Silaban, 2020). This model is currently referred to as the dual language program (Lindholm-Leary, 2013; Massachusetts Department of Elementary and Secondary Education (MDESE), 2020).

\section{Submersion and Immersion Programs}

A submersion program does not take care of language diversity in the classroom (Hornberger,1990), only the language supported by policy is used. There are no supporting materials for the use of L1 (MDESE, 2020). When support for the use of L1 is provided, the program is called immersion. Scholars suggest that both submersion and immersion programs lead to 'low achievement and high dropout rates, especially among minorities who sometimes perceive their status as low relative to the majority children' (Ovando and Collier, 1985, p.43). An example of a submersion program was one operating in Botswana for the non-Tswana language groups. They are submersed into Setswana, a second language and later again submersed into English, a third language while their mother tongue was not allowed in the classroom. This is the model in operation at Muzi.

The arguments by the two camps of the second Commission indicated the orientation of language diversity being viewed as a right and a resource on one hand (Camp A), and as a problem on the other hand (Camp B). Camp A's arguments are pedagogically inclined, with a focus on the child, considering the language in which they would benefit from instruction most and acquire literacy skills. Camp A, like the First Commission viewed mother tongue as a resource which facilitates the acquisition of literacy skills in the second language (Duplessis and Tibategeza, 2010).

Underlying Camp B's arguments is the orientation of language diversity viewed as a problem. They see the development of many languages as too costly and as not deserving the effort. The Camp reasons that such effort would be denying children the opportunity to learn the most important language, namely English. They did not embrace the view that learning in mother tongue facilitates better acquisition of a second language (Duplessis and Tibategeza, 2010).

The arguments for Camp B have little to do with learning but with economics and business. They are not internally focused by external in outlook, and yet learning is a reality on the ground. The question then is, how can children be businesspeople of tomorrow if they cannot read and write. The arguments were ignoring the means to achieve the goal.

Until recently, language diversity in Botswana was viewed generally as a problem, a reversal or negation of democratic gains, a threat to unity, social harmony, and development (Nyati-Ramahobo, 1999). Tsonope (1992) noted that '-- to raise language policy issues even where these are articulated in the best interest of the country are met with suspicious contempt - invoking secessionist, tribalistic, regionalistic or other sentiments deemed inimical to national unity and progress' (p.10).

This was yet another misconception, that unity can only be achieved by sweeping the rest of the languages under the carpet and assimilating their speakers. In fact, the contrary is true. When people are respected, recognized and their languages are valued, they have no reason to rise in revolt on linguistic grounds. But when they are swept under the carpet, that is a good reason to agitate. Camp B and the then Government of Botswana did not believe in the concept of unity in diversity. The first President informed the nation that his party 'stands for a gradual but sure evolution of a nation state... to which tribal groups will, while in existence, take secondary place' (Carter and Morgan, 1980, p.291). In 1989, the second President asked Batswana 'not to spoil the prevailing peace and unity in the country by fighting for ethnic language groupings' (Republic of Botswana, 1989, p.1).

However, despite this orientation, speakers of other languages have been agitating, and the fifth president has made pronouncements to develop these languages for education and instruction is planned to begin in 2022. Consultations are on-going to inform communities on this initiative. Some linguistic groups had long started to develop their languages and conducting informal classes. Perhaps the fifth President will see the development of a more robust language policy 
to view linguistic diversity as a right and a resource. The country is yet to see which type of language program will be recommended for use in 2022. The development of the language in education policy and language policy in general has come a long way and there seem to be light at the end of the tunnel.

\section{LITERATURE REVIEW}

The education structure from primary to secondary is 7:3:2. In accordance with the language policy as informed by the orientations as described above and the program types that emanated from them, teachers are expected to teach in Setswana from standard one to two and in English from standard three onwards. However, this is not the case in some schools, as has been documented by several studies (Nyati-Saleshando, 2018a); International Reading Association (IRA 2005). Most of the teaching takes place in Setswana and English from standard one to seven with evident codeswitching (Ketsitlile and Commeryas, 2014). Some scholars have asserted that, it is this unplanned code-switching and concurrent medium that enhances learning, otherwise, the pass rates in standard seven where English is supposed to be the sole medium of instruction would be lower than the current situation (Chebanne and Dlali, 2019). The submersion model, however, remains in other schools such as Muzi, without switching to their local languages.

Studies have further demonstrated that some minority languages such as Kalanga and Subia have been informally introduced at both primary and secondary levels (IRA, 2005). The areas where these two languages are dominant (Chobe and Northeast districts) perform better than minority dominated areas in the Primary School Leaving Examination (PSLE) (BEC, 2000-2020). On the other hand, the areas of Northwest, Kgalagadi and Ghanzi districts, which are linguistically complex with no one minority dominant language, have been performing the worst since independence without any affirmative action to address the situation (Nyati-Ramahobo, 1997; Nyati-Saleshando, 2018a).

Mokibelo (2018) asserted that children in rural areas found it difficult to learn English. She concluded that poor English proficiency resulted in low academic achievement. She further observed that students had poor comprehension and basic language skills, and this negatively affected academic performance. She acknowledges the need for mother tongue education in these areas. The agitation for mother-tongue education has been going on since independence and has intensified in recent years.

Studies on teacher attitudes and its impact on students' performance conclude that positive attitudes result in positive student academic performance (Azmat, 2019; Ulug, Ozden and Eryilmaz, 2011). In Botswana, Nyati-Ramahobo (1994) found that most teachers in schools had negative attitudes towards students in minority areas. They were impatient and used negative language in reacting to 'wrong' responses in class, and to inappropriate behavior. This situation seemed to have improved since it was not so evident at Muzi school. Perhaps this change could be attributed to the public debate on language issues which started in 1995.

\section{METHODOLOGY}

Data was collected in 2018 and a total of ten (10) lessons in social studies, English, Setswana, and Science were observed in standards 1, 3, 5, 6 and 7. A questionnaire was administered to 30 teachers and 19 were returned for analysis. Physical interviews were conducted with ten (10) teachers and eleven (11) students in standards 6 , and 7. Interviews questions for teachers were to triangulate the responses to the questionnaire and classroom observations. In 2021, five follow up interviews were carried out telephonically with teachers to update the demographics of the school and revisit key questions of the study. All interviews were conducted in Setswana language, but informants were free to respond in any language. Most of them used code-switching between Setswana and English.

Content analysis was utilized to analyze data from interviews, classroom observations and the open-ended questionnaire. Both the interview and questionnaire were structured according to the four main questions the study sought to address. The main approach to content analysis was the conventional one in which coding categories derive from text data, searching for themes of the main questions and finding coherence in data from the three instruments (classroom observation guide, semi- structured interviews, and the questionnaire). The internal reliability of data from the three instruments provided both triangulation and trustworthiness.

\section{FINDINGS}

Data was analyzed to find out teacher perceptions on why the school was under performing, whether they thought language of instruction had a role to play in academic performance, if there were any observable attitudes within the school environment which could have an impact on learning, and what were the implications of their observations on nation building, social integration, and democracy. Embedded within each theme was the question of what could be done.

\section{A. Teacher Perceptions on Low School Performance}

Teachers were asked to give what they believed were reasons for the low performance of the school. They provided several reasons as follows: 


\section{Lack of Learning Resources.}

Lack of a library was pointed out to be a major impediment to teaching and learning. Students were reported to be sharing books and at times parents had to buy notebooks for their children. The school photocopier had not been working for some time. Teachers were also sharing textbooks, and this was described as major setback in preparing for classes. Lack of teaching materials resulted in teachers having to write everything by hand on the board and even draw pictures a skill most said they did not have.

\section{Lack of Motivation to Learn.}

Teachers also stated that, when they visited homes, they rarely found children doing their schoolwork. Few children were viewed as serious about their schoolwork and parental participation in learning was described as minimal.

\section{Neglect of the Okavango Sub-District by the Main Northwest District Council.}

The outstanding concern was that the school had been underperforming for years and yet not much had been done. This situation was reported be observable across sectors, not just in education. In 2021 teachers acknowledged that the situation had improved over time, and they are able to have materials such as manila paper to use in the classroom. On the use of technology in the classroom, they decried this phenomenon yet to come to the school.

\section{Untrained/Temporary Teachers}

While the issue of untrained teachers came up in 2018, it was not emphasized in 2021. Improvement in this area was acknowledged as the Ministry of Basic Education was reported to employ degree holders on temporary basis even if they were not trained as teachers and this has improved the standards of teaching. In 2021, there were twelve (12) temporary teachers at the school. The researchers were able to meet one of them in 2018, though their class was not observed. The teacher felt that teaching was an enjoyable job but needed resources to innovate. They also felt that temporary employment was not motivating as it did not provide job security. They felt classified as not 'real' teachers.

When teachers were asked which of the above issues was the most pressing to be addressed as a matter of urgency, most pointed to resources and student motivation as critical. They felt that teachers need resources to teach, and they find themselves being unable to innovate ideas, but rather must innovate the use of resources which limits their ability to teach concepts more effectively. Overall, teachers felt that while some of the above issues persist, there had been effort to address them, such as the provision of copiers, even though repairs and replacements took long. These were pressing issues which impacted on teaching and learning.

\section{Lack of Parental Presence and Value for Education}

Some children were reported to live with other siblings while parents were engaged in small scale farming, fishing, and gathering elsewhere. As a result, children had no one to encourage learning activities. One teacher stated that, even failure to perform well in the PSLE is not taken seriously by parents, since it has been a common phenomenon in the village for years. Education is therefore associated with low academic achievement as its benefits are not commonly experienced by most parents, hence it is devalued. A teacher reported a case in which a child passed standard seven with a B grade but decided not to go for further education because the parents preferred, he goes to help with farming activities.

\section{Long Distance to School}

Neighboring villages have no schools, and a such, children from these villages walk each morning to school and back home every day. 'They come to school late and tired' said one teacher. Teachers felt that these children in most cases leave home without any breakfast and only eat during break time at the school. This affects student attention and interest in learning.

\section{B. Role of Language of Instruction}

When asked whether they believed that the language of instruction had a role to play in the performance of the children, hence the school, all teachers responded in the affirmative. 'When a child does not understand the language, they cannot learn', said one teacher. Children from the Hambukushu tribe were reported to have communication problems in Setswana during the first two years of schooling. 'They begin to pick up in standard three' a teacher said. In standards one and two, they would respond in their own language or keep quiet, and since most of the teachers were from other linguistic groups, communication was difficult during those initial years. Teachers felt that the language of the children should be used. One teacher however, felt that while this was a noble idea, it could confine teachers to their linguistic areas.

At home, the Wayeyi children speak the Setawana dialect of Setswana spoken in the district. Their initial year at school is not as difficult with regards to general communication, but with comprehension of concepts in the classroom. The dialect has a lot of Shiyeyi vocabulary and Shiyeyi underlying sentence structure (Nyati-Ramahobo, 1994). As children use these words at home, they believed they were Setswana words. As such children do not understand why they get low marks in Setswana hence get discouraged. While they think the Setawana dialect they speak as a second language is the standard Setswana, this was not the case. The Setawana dialect of Setswana is different from the 
Setswana used in the classroom, and this creates confusion in learning. Research indicates that the familiar the language of instruction to the language of the learner, the difficult it is for learners to see the difference and comprehend the target language (Pica, 1991). Some teachers, especially, those outside the district, had problems understanding children's language and vice versa.

Teachers felt the need to use the language spoken by children. One teacher wished they could speak these languages to facilitate student centered and interactive learning. The use of English and Setswana as main medium made meaningmaking in the learning process difficult. Generally, children were shy, quiet and inactive in classes. Classroom interaction was low in most classrooms, more so in English medium lessons, but better when Setswana was allowed even when the expected medium was English.

Children had problems understanding Setswana as spoken by teachers who were native speakers of Setswana who lived outside the Northwest district. Interviews with these teachers indicated that children do better in English than in Setswana. Classroom observations demonstrated that, teachers in upper grades tried to use English as much as possible in accordance with the policy, while those in lower grades used Setswana. The languages of the children were not part of the learning process. Interviews with students in 2018 indicated that they understand teachers from the Northwest district ${ }^{1}$ better, when speaking in both Setswana and English. They further stated that Hambukushu teachers used Thimbukushu words in class, though only in rare occasions, while Wayeyi teachers used Shiyeyi cultural themes to illustrate certain topics in social studies.

\section{Teacher Attitude and Its Impact on Learning}

At the classroom level, no overt attitudes were observed which could negatively impact on learning. Most teachers relied on one or two students whom they knew would respond, while the majority were quiet. The silence in classrooms was defined as a cultural issue of not questioning adults, or just lack of language skills to interact in the classroom. Interviews with teachers revealed that some teachers were impatient with children, and this seemed to discourage them. Attitudes such as 'what is wrong with children from this area' is an attempt to explain children's low performance as something 'wrong' with them. However, this was not emphasized as a major issue at the school.

\section{Implications for Nation Building, Social Integration, and Democracy}

Most teachers felt that Botswana is integrated using Setswana. The issue of language in the classroom should no longer be seen as a dividing factor, but a further unifying one. 'Re tshaba eng gore diteme tse dingwe di rutwe, kana ga gotwe go lathwe Setswana, re batla mongwe le mongwe a utlwa se se rutwang' (What are we afraid of, we are not saying Setswana should be eliminated, we want all children to understand what is being taught). This view expressed the orientation of unity in diversity for nation building.

One teacher however, stated that, 'bana ba baa utlwa, ke gore ba boi, ga ba ithute ko malwapeng, Setswana ke yone teme ya rona mo Botswana, re Batswana' (these children do understand, it is just that they are afraid to speak in class, and they do not study at home. Setswana is our language in Botswana, we are all Batswana). This view reflects intolerance to unity in diversity, but rather for assimilation into the Tswana language and culture. However, this was a minority view at the school.

Follow up interviews in 2021 indicated that, government's decision of 2021 to start mother tongue education in 2022 was a welcome development. They however, felt that it was not adequately prepared for and may fail. They felt that such failure may be misinterpreted to mean failure of mother tongue education when in fact, it would be failure at the implementation level. It was generally felt that democracy is about taking care of the venerable and helping everyone to participate in the economy through education.

Teachers could not easily recall integrated social groups but stated that they see children playing along and across class levels and ethnic lines. They stated that within Muzi, the village chief is a Hambukushu. He does not have a good relationship with the Wayeyi village chiefs. The Wayeyi had negative attitudes towards Hambukushu and view them as of lower social status. Such divisions were also reported to be noticeable in the school, though not to a large extend. Most teachers felt that the answer lies in getting children to learn each other's language and culture to cultivate appreciation of the other. This indicated that while the government had believed, as indicated by the debate of the first Commission (1977), that monolingualism in Setswana would yield social integration, the opposite has been the case, depending on the social factors in specific environments. The gain has been essentially, the use of Setswana around the country while agitation for other languages was on-going in the hearts and minds of the people.

\section{DISCUSSION}

Practice at Muzi Primary school depicted an assumed monolingual setting, while it was multilingual. It was loyal to the language policy as stipulated by the Second National Commission on Education (1993). The arguments for mother tongue education contained in Appendix F of the report were ignored. Both policy and practice were influenced by the

\footnotetext{
${ }^{1}$ Most children did not know where their teachers come from but mentioned them by name and the researchers had to follow up on where they came from.
} 
orientation of language as a problem - a burden to the education system. Failure rate in schools such as Muzi were not viewed as a problem to be addressed.

The policy was a silencer in multilingual classrooms, an impediment to interactive and student-centered learning, and a barrier to the implementation of the communicative approach to language teaching which government espoused. The model was submersion into Setswana and English for Muzi students. The languages of the learners played no role in the learning process. Teachers felt this was a contributing factor to the low performance of the school among others. The national language Setswana is spoken in most parts of the country with different levels of competence and dialects which are not equivalent to the standard repertoire meant for the classroom. The attitudes of some teachers who believed that Setswana is the only language that should define the citizenship of Botswana, could be detrimental to the learning process in non-Tswana dominated classrooms, resulting in low performance. Such attitudes are counterproductive to nation building, contrary to democratic principles and work against the concept of unity in diversity.

Research has indicated that when people are linguistically discriminated against, they are in most cases socially, economically, and politically discriminated against (Gandara, Losen, August, Uriarte, Gomez, and Hopkins 2010). They assert that bilingual education programs by themselves would not address low performance in minority children if poverty and discrimination continue. This is the case with Muzi as indicated by the assertion that the district was neglected. Travel within the district is a challenge due to the conditions of the roads. Parts of the Okavango sub-district have never had a tarred road since independence. The lack of resources is further evidence of this discriminatory phenomenon. The chronic failure rate at Muzi school has resulted in the de-valuation of education by parents, who would prefer the children to join them in economic activities such as farming to address poverty than 'waist' time at school.

Research has further indicated that the ability to speak more than one language improves brain function, cognitive flexibility, better memory and promotes problem-solving skills (Calderon, Dove, Fenner, Gottlieb, Honigsfeld, Singer, Soto, and Zacarian, 2019), and enhances the learning of English (Duplessis and Tibategeza, (2010), when the child's first language is made part of the learning process. These advantages of multilingual education, need to be harnessed to improve the education system in Botswana which has been on the decline (Nyati-Saleshando, 2018a; Commeryas \& Ketsitlile, 2013).

Nyati-Saleshando (2018a), when analyzing the 2015 report on Trends in International Mathematics and Science Study (TIMSS), BEC (2016) observed that out of the ten districts in Botswana, four were performing below average, and all were dominated by constitutionally unrecognized linguistic groups. The two minority dominated areas of Chobe and Northeast which were performing above average, have each one dominant language (Subia and Kalanga respectively), and these languages have been unofficially introduced into the classroom (Nyati-Ramahobo, 1994; IRA, 2005; Ketsitlile and Commeryas, 2014; Spaull, 2011). Students do better in these areas than those where no dominant minority language is used in the classroom such as Northwest, Ghanzi and Kgalagadi districts (BEC, 2000-2020). While the other three districts (Central, Kweneng and Southern), are minority dominated, these populations have been linguistically and culturally assimilated by the recognized Tswana groups they still under-perform. This is further evidence for the need to use mother tongue in education, especially in rural non-Tswana dominated areas (Mokibelo 2015).

The government's pronouncements to introduce local languages in schools in 2022 (Ghana News, 2021), was viewed as a positive response to a chronic problem, an installation of democratic principles and nurturing of social justice. It needed planning and resourcing to implement this noble idea with success. National unity can be achieved when all stand to benefit from the education system which recognizes and empowers the learner for economic prosperity. This is determined by the choice of appropriate policies, classroom methodologies, relevant materials, and competent teachers.

\section{CONCLUSION}

Muzi is an example of a school which is dominated by children who speak languages that are different from the school language. Districts such as Ghanzi, Kgalagadi, Southern and Kweneng west are such areas, and performance has been low since independence in all these areas. Factors affecting student academic performance include lack of resources, lack of motivation to learn, equity issues within the district regarding resource allocation.

Language of instruction was found to be another major factor in student performance. While negative attitudes were observed at the community level, they were not perceived to be a major factor at the school level. This study concludes that equity issues in education persisting over a long time have negative implications for democracy, social integration, and nation building. The pronouncements by the fifth President to introduce local languages in schools are a step in the right direction towards achieving democracy. They reflect an orientation of language diversity being viewed as a resource to be developed and nurtured and a right to be enjoyed. If properly planned and implemented, these efforts will provide literacy in mother tongue, to as many citizens as possible. It would promote linguistic and cultural pluralism and cultivate unity in diversity, and most importantly, improve academic performance, hence economic advancement.

The utilization of current methodologies such as translanguaging and code-switching in a maintenance model program would go a long way in improving self-worth among learners, improve student performance and foster social 
integration, factor which have been found to contribute to academic achievement in schools. Strategic pathways to material production, local teacher induction and community involvement are key factors in moving forward.

\section{REFERENCES}

[1] Azmat, H. (2019). The influence of teacher attitude on student achievement at grade six, elementary school Hyderabad. Unpublished report. Government Elementary School College of Education (Women) Hyderabad. https://dx.doi.org/10.2139/ssrn.3756379

[2] Alidou, H. (2010). Use of African languages for literacy: Conditions, factors and processes in Benin, Burkina Faso, Cameroon, Mali, Tanzania, and Zambia. In A. Ouane, \& O.Glanz (eds.), Optimising learning, education and publishing in Africa: The language factor. A review and analysis of theory and practice in mother tongue and bilingual education in Sub-Saharan Africa (pp. 216-252). UNESCO.

[3] Alstad,G.T, \& Sopanen, P. (2020). Language orientations in early childhood education policy in Finland and Norway. Nordic Journal of Studies and Educational Policy, https://doi:10.1080/20020317.2020.1862951

[4] Benson, C. (2020). An innovative 'simultaneous' bilingual approach in Senegal: promoting interlinguistic transfer while contributing to policy change. International Journal of Bilingual Education and Bilingualism, https://doi.org/1080/13670050.2020.1765968

[5] Bretuo, P. (2021). Using language to improve learning: teachers' and students' perspectives on the implementation of bilingual education in Ghana. Language Culture and Curriculum, 34(3), 257-272, https://doi.org/ 10.1080/07908318.2020.1825470.

[6] Botswana Examination Council (BEC). (2000-2020). Primary School Leaving Examination (PSLE) results for 2000, 2015, 2019 and 2020). Retrieved June 6, 2021, from www.bec.co.bw.

[7] Botswana Examination Council (BEC). (2016). A summary report of Botswana performance trends in international mathematics and science study (TIMSS) 2015. Retrieved June 6, 2021, from.www.bec.bw. Retrieved June.

[8] Calderon, M.E., Dove, M.G., Fenner, D.S., Gottlieb, M., Honigsfeld, A., Singer, TW., S.W.,Soto, I., \& Zacarian, D. (2019). Breaking Down the Wall: Essential Shifts for English Language Learners, National Education Association (NEA) Retrieved August 1, 2021, https: www.amazon.com

[9] Carter, G. M., Morgan, P. (1980). From the Front-Line: Speeches of Sir Seretse Khama. Rex Collins.

[10] Chebanne, A., \& Dlali, M. (2019). The Curse of Poverty and Marginalization in Language Development: The case of Khoisan Languages of Botswana. SPiL Plus, (58), https://dx.doi.org/10.5842/58-0-844

[11] Commeyras, M. \& L. E. Ketsitlile (2013) A review of the literature on reading in Botswana primary schools, Africa Education Review, 10 (2), 204-223. DOI:10.1080/18146627.2013.808794.

[12] Conklin, N., Lourie, M. (1983). Policy and education in a multilingual society. In N,Conklin \& M. Lourie (Eds.) Host of Tongues: Language communities in the United States, (pp. 225-245). Free Press.

[13] de Jong, E., Coulter, Z., \& Min-Chuan, T. (2020). Two-way bilingual education programs and sense of belonging: Perspectives from middle school students. Journal of Bilingual Education and Bilingualism, https://doi.org/1080/13670050.2020.1783635

[14] Duplessis, L., \& Tibategeza, E. (2010). Implementation of bilingual education in Tanzania: The realities in the schools. Canadian Journal of African Studies, 19 (4), 227-249.

[15] Fishman, J.A. (1976). Bilingual education is good for education. In J.A. Fishman (ed.), Bilingual education: An international sociological perspective (pp. 23-31) Newbury House.

[16] Gandara, P., Losen, D., August, D., Uriarte, M., Gomez, M. C., \& Hopkins, M. (2010). Brief history of U.S. language policy. In P. Gandara \& M. Hopkins (Eds.), Forbidden language: English learners and restrictive language policies, (pp. 20-32). Columbia University Press

[17] Hamman-Ortiz, L. \& Palmer, D. (2020). Identity and two-way bilingual education: Considering student perspectives: introduction to the special issue. International Journal of Bilingual Education and Bilingualism, 23 (3), https:// Doi. 10. 1080/13670050.2020. 1819096

[18] Hornberger, N. (1987). Bilingual education and Quechua language maintenance in Highland Puno, Peru. NABE Journal, 11(2), 117-140.

[19] Hornberger, N.H. (1990). Extending enrichment bilingual education: Revisiting typologies and redirecting policy. In O. Garcia (Ed.) Festschrift for Joshua A. Fishman, Focus on Bilingual Education. (Vol.1, pp. 215-238). John Benjamin Publishing Company.

[20] Hult, F.M. \& Hornberger, N.H. (2016). Revisiting orientations in language planning: Problem, right and resource as an analytical heuristic. Bilingual Review, 33(3), 30-49

[21] International Reading Association (IRA). (2005). Improving the quality of literacy learning in the content areas: A situational analysis of secondary level education in Botswana. UNESCO Section for General Secondary Education Division of Secondary, Technical and Vocational Education. Retrieved April 6, 2018, from https://researchgate.net/publication/321361563

[22] Ketsitlile, L. E \& Commeyras, M. (2014). Reviewing published information on reading in Botswana secondary schools. Reading and Writing, 5 (1). Article no. 35. Retrieved April 20, 2018, www.rw.org.za/index.php/rw/article/view/35/125

[23] Lindholm-Leary, K. (2013). Education: Dual language instruction in the U.S, American Quarterly Update on Policy, 7, 97-98.

[24] Massachusetts Department of Elementary and Secondary Education. (2020). Transitional bilingual education program. Retrieved July20, 2021, Doe.mass.edu/ele/programs/tbe.html

[25] Mibenge, C. (2016). English language: A 'tool' for social connectedness: A study on native teens in Botswana. Power and Education, 8(2), 196-202. Retrieved July20, 2021, from https://doi.org/10.1177/1757743816651897

[26] Mokibelo, E.B. (2018). Language in education policy and Marx's views on education. International Journal of Scientific Research and management, 6(4), 292-298.

[27] Mokibelo, E.B. (2015). Multilingualism and multiculturalism in the education system and society of Botswana. US-China Education Review, 5(8), 488-502. 
[28] Mokibelo, E.B. (2014). The national language as a language of instruction in Botswana primary schools. Language and Education, 28(5), 421-435. https://doi.org/10.1080/09500782.2014.892126

[29] National Commission on Education. (1977). Education for kagisano. Government Printer.

[30] National Commission on Education. (1993). Report of the National Commission on Education. Government Printer.

[31] Nyati-Saleshando, L. (2018a). Research on language and literacy in Botswana: Mapping the Agenda. Mosenodi: Journal of the Botswana Educational Research, 21 (2), 29-43.

[32] Nyati-Saleshando, L. (2018b). Managing linguistic diversity and academic performance through dual language program in California, Marang: Journal of Language and literature, 30, 71-89

[33] Nyati-Saleshando L. (2011). Advocacy Project for Multicultural Education in Botswana: The Case of Shiyeyi Language in Botswana. International Review of Education, 57(5), 567-582. DOI: 10.1007/s11159-011-9254-4

[34] Nyati-Ramahobo, L. (1999). The national language - a resource or problem: The implementation of the language policy in Botswana. Pula Press

[35] Nyati-Ramahobo, L. (1997). Language in education and the quality of life in Botswana. In D. Nteta and J. Hermans (Eds.), Poverty and plenty: The Botswana Experience, (pp.251-269). The Botswana Society.

[36] Nyati-Ramahobo. (1994). Minority language use and early educational hurdles in Botswana, Pula: Botswana Journal of African Studies. 8 (1), pp.90-103.

[37] Ovando, C.J. and Collier, V.P. (1985). Bilingual education and ESL classrooms: Teaching in multicultural contexts. McGrawHill.

[38] Pica, T. (1991). Classroom interaction, negotiation, and comprehension: Redefining relationships. Systems, 19 (4), 437-452

[39] Republic of Botswana. (1994). Government Paper No.2 of 1994: The Revised National Policy on Education. Government Printer

[40] Republic of Botswana. (1985). National Development Plan 6: 1985-1991. Government Printer.

[41] Republic of Botswana. (1989). Daily News, June 30, 1989, number 123). Government Printer.

[42] Ruiz, R. (1984). Orientations of language planning. NABE Journal 8(2), 15-34.

[43] Silaban, R. (2020). The implementation of bilingual education program at SMK N.1 Sidikalang in academic year 2018/2019. Jurnal llmiah Skylandsea, 4 (2), 20-27. Retrieved August 3, 2021, https://www.politeknikmbp.ac.id

[44] Spaull, N. (2011). Primary school performance in Botswana, Mozambique, Namibia, and South Africa. SACMEQ Working Paper 8. Retrieved April 20, 2018, from www.sacmeq.org/sites/default/files/sacmeq/publication/08comparisons_final_18oct2011.pdf.

[45] Trueba, Henry. (1979). Bilingual education model: Types and designs. In H. Trueba \& Barnett-Mizrahi (Eds.) Bilingual Multicultural Education and the Professional: From Theory to Practice. Pp.54-73). Newbury House.

[46] Tsonope, J. (1992). Language as a Resource. Kutlwano Magazine, 30 (8), 10-11.

[47] Ulug, M., Ozden, M.S., \& Eryilmaz, A. (2011). The effects of teachers' attitudes on students' personality and performance. Procedia-Social and Behavioral Sciences, 30, 738-742

[48] Xinhua, L. (2021). Botswana to introduce 11 local languages in schools in 2022. Ghana News, September 16, 2021. Newsghana.com.gh.

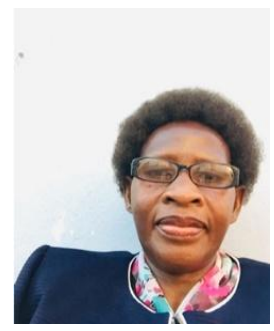

Lydia Nyati-Saleshando (nee Ramahobo) was born at Ikoga village in the Okavango delta, Botswana in 1957. Educational qualifications are a Bachelor of Arts, concurrently with a Diploma in Education from the University of Botswana and Swaziland in 1982, Gaborone Botswana. A Master of Science in Education, University of Pennsylvania, Philadelphia, USA, 1985, and a PhD in Applied Linguistics from the University of Pennsylvania, Philadelphia, USA, 1991.

She is currently a Professor of Education, in the Department of Primary Education, at the University of Botswana. She served as Head of Department, Dean of the Faculty of Education and as Deputy Vice Chancellor, Student Affairs, from 2006 to 2015. Her publications include the following:

[1] Nyati-Ramahobo, L (1999). The National Language. A Resource or A Problem: Implementation of the Language Policy of Botswana. Pula Press.

[2] Nyati-Ramahobo, L (2006). The Long Road to Multilingual Schools in Botswana. In O. Garcia, T. Skutnabb-Kangas \& M. Torres-Guzman (eds), (2006). Imagining Multilingual Schools: Language in Education (pp. 200-219). Multilingual Matters.

[3] Nyati-Saleshando, L. (2019). Shiyeyi language planning in Botswana: International connections and local imperatives. Journal of Language, Identity and Education, DOI: 10.1080/15348458.2018.1552148. Retrieved July 6, 2021. Her research interests are language planning and policy, bilingual education, second language acquisition and literacy.

Professor Saleshando was the recipient of the William E. Arnold Award - for outstanding performance and leadership qualities at the Graduate School of Education, University of Pennsylvania, in 1991. Prof Saleshando was awarded the Certificate of Recognition for outstanding accomplishments and contributions to the social welfare, political and economic advancement of rural women of Botswana (Department of Women's Affairs, Ministry of Labor and Home Affairs), September, 2006. She served as a member of the Governing Council for Minority Rights Group, London, UK, (October 2005 - October 2012), and currently a member of the Peace Women Around the Globe (PWAG) since 2005. 


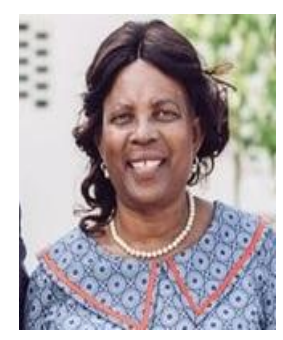

Rosinah T. Mokotedi was born at Ramotswa village, Botswana in 1958. Qualifications are as follows: Ed. D (TESOL), Exeter, UK, 2012; M. Ed (TESOL), Newcastle UPON Tyne, UK, 2000; B. Ed (Primary Education), University of Botswana, 1995; Primary Teachers' Certificate at, Serowe Teacher. Training College, Botswana, 1980.

She is a lecturer in the Department of Primary Education, University of Botswana. She developed MAPEP Botswana learner's textbook and teacher's guide for standard 1 pupils, published by Macmillan Boleswana. The books are used as textbooks in Botswana Primary Schools. Selected peer review publications are as follows:

[1] Mokotedi, R. T. (2013). Beginning Primary School Teachers' Perspectives on the Role of Subject Specialization in Botswana Colleges of Education: Implications for the Professional Development of those who did not specialize in Languages (English and Setswana). International Journal of Scientific Research in Education, 6(1), 88-99

[2] Mokotedi, R. T. \& Mhlauli, M. B. (2017). Teachers' perspective on learning strategies utilised by standard five ESL learners in reading for comprehension across the curriculum in Primary Schools in Botswana. IJSRE, 10(5), 505-519.

[3] Mhlauli, M.B., Salani, E \& Mokotedi, R.T. (2015). Understanding Apartheid in South Africa through the Racial Contract, International Journal of Asian Social Science, Retrieved September 3, 2017, from http: //www.aessweb.com/journals /5007.

Her research interests are in approaches to language teaching and learning, children's literature, language acquisition, academic literacy, and teaching reading in a Second Language

Dr Mokotedi teaches courses in language education such as drama for young learners, reading, the project method and assessment. She serves as the Departmental examinations' coordinator, library and bookstore coordinator. 